\title{
Effect of Application of Learning Model Group Investigation on Critical Thinking Ability of Mathematical High School Students
}

\author{
Sadikin ${ }^{\text {a) }}$ Fahinu, Ruslan and Kadir \\ ${ }^{I}$ Department of Mathematics Education, Halu Oleo University, Kendari, Indonesia \\ ${ }^{2}$ Department of Statistics, Halu Oleo University, Kendari, Indonesia

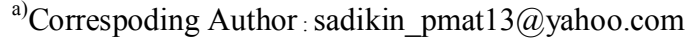

\begin{abstract}
Critical thinking skills of mathematics students are still low. Teachers lack training critical thinking ability of students during learning. This study aims to examine differences influence learning model group investigation andconventional learning models to the critical thinking skills of mathematics students. The research design was pretest posttest control group design. The study population was all students in grade X SMAN 3 Kendari comprising 9 parallel classes. Samples were taken by purposive sampling, such as taking two classes that have the mathematical ability and the variance is relatively the same. Both classes were then randomized to determine the experimental class (34 students) and control class (32 students). Data collected through the provision of critical thinking skills tests as essay test form. Data was analyzed by descriptive and inferential test using t test at the 0.05 significance level. The results showed that: (1) there is an effects of the application of learning model group investigation of the critical thinking skills of mathematics students with an average N-Gain of 0.55 (medium); (2) there is an effect of the application of conventional learning models to the critical thinking skills of mathematics students with an average N-Gain of 0.283 (low); and (3) application of the learning model group investigation is more influential than the application of conventional learning model to mathematics students' critical thinking skills.
\end{abstract}

\section{INTRODUCTION}

Mathematics instruction given by the teacher is expected to hone the students so that they have a basic competency in mathematics, which is understanding, problem solving, thinking, reasoning, and mathematical communication [1]. Critical thinking ability of mathematics is something that is very important in modern life, because it can make people become more open and easily adapt to various situations and problems. Critical thinking ability of mathematics for example, appears in the form of: (1) identify the completeness of the premise of a statement (issue), (2) define the concept in resolving problems with precision, (3) applying the concept to create a mathematical model in solve the problems, (4) shows results the main and procedures in problem solving and (5) test back and determine the conclusion of a problem.

The results of observations conducted in 2014 showed that the study of mathematics in grade X SMAN 3 Kendari still not able to maximize the critical thinking ability of mathematics students. The ability of students is still low in every aspect of critical thinking ability. This looks at the percentage every aspect of critical thinking ability of mathematics students'. From the five (5) question of the given, where the ideal score for each indicator was 20 , obtained an mean score of the students' ability in the aspect of trigger event reached $53.33 \%$, scores of students ability on aspects of the exploration reached was $4.26 \%$, analyze aspects reached was $25.37 \%$, clarifying aspects reached was $16.11 \%$, and aspects of the resolution reached was $6.85 \%$. It appears that scores the lowest aspect is the aspect of exploration, is the ability of students to explore mathematical ideas, which led to the following aspects not optimal so the issue or question is not resolved systematically.

Learning model that teachers applied not involve students actively and mathematics questions that teacher given to students not allow students to work in a variety of ways as well as systematic. This can be identified from the activity at the time the teacher explains the material in front of the class. Teachers are still applying teacher-centered learning, where teachers explain the material to the media PowerPoint while students pay attention to it. Based on interviews with teachers, mathematics ability class X SMA Negeri 3 Kendari quite well that the average value of 79.6 and students quite actively ask in the learning process and the students had no trouble solving question of 
mathematics. However, they are not optimal in analyzing mathematical question. When students are given questions that differ from the questions usual given by the teacher or non-routine question as a question of problem solving, students' difficulties solved the problems because only familiar with the application of formulas that have been there before. So that students tend to directly write the final outcome of the questions of the teacher, without a systematic way.

Improving students' critical thinking ability mathematics in mathematics learning, requires an appropriate learning models. Learning is a learning experience that is more meaningful in accordance with students' thinking ability as well as with regard to daily life, so that students can view mathematics as a subject that is fun is not as difficult subjects, scary, boring and even confusing. Thus it can motivate students to learn more actively. One model of learning is more emphasis on the activity of students to develop their maximum potential in solving problems in mathematics learning is group investigation (GI) learning model.

Group Investigation comes from the educational philosophy of John Dewey. Dewey believes that meaningful learning can be generated through the stages of scientific research, where students gain knowledge from experience [2]. Group Investigation Model, also called cooperative learning the most complex [3]. This is caused by this method combines several premises, which is based on the constructivist view, democratic teaching, and cooperative learning groups. Understand constructivist argue that knowledge will be formed or awakened in the mind of the student himself when he attempted to organize a new experience based on a cognitive framework that already exists in his mind. This model does not require students to memorize facts, but encourage students to construct their own mind [4].

\section{METODOLOGY OF RESEARCH}

This research was Quasi Experimental pretest-posttest control group design, implemented in class X SMA Negeri 3 Kendari Propinsi Sulawesi Tenggara, in the second semester of the school year 2014/2015. Population of the study were all students of class X in the academic year 2014/2015 SMA Negeri 3 Kendari consisting of nine parallel classes. Samples were taken by purposive sampling technique that takes two parallel classes were homogeneous. Then to choose experimental class and control class used random class that is one class experiment (X3) and the control class (X4). Data analysis techniques used descriptive statistical analysis and inferential analysis. Hypothesis testing was done by t-test.

\section{RESULT OF RESEARCH}

Test of critical thinking ability mathematics consists of 5 items on the subject congruency to pretest and 5 items on the subject trigonometry to posttest. Data Description critical thinking ability of mathematic students' are presented in Table 1.

TABLE 1. Data Description the Critical Thingking Ability of Mathematics Students

\begin{tabular}{lcccccc}
\hline \multirow{2}{*}{ Statistic } & \multicolumn{6}{c}{ Learning Model } \\
\cline { 2 - 7 } & \multicolumn{3}{c}{ Group Investigation } & \multicolumn{3}{c}{ Konventional } \\
\cline { 2 - 7 } & Pretest & Posttest & N-Gain & Pretest & Posttest & N-Gain \\
\hline $\mathrm{N}$ & 34 & 34 & 34 & 32 & 32 & 32 \\
Mean & 19.24 & 63.15 & 0.55 & 18.81 & 41.63 & 0.29 \\
Standar Deviation & 5.15 & 11.49 & 0.12 & 6.27 & 14.67 & 0.13 \\
Maximum & 29.00 & 85.00 & 0.80 & 31.00 & 67.00 & 0.55 \\
Minimum & 11.00 & 43.00 & 0.32 & 7.00 & 18.00 & 0.09 \\
\hline
\end{tabular}

Data of student activity on the use group investigation learning model obtained from the observation of the student. From the analysis it can be seen that most students in the class of 34 students, they had done what they were supposed to do in a learning process, is to perform the activity of students in response to the instructions/questions the teacher and student activity in group discussion activities and class discussions, the results of these observations are presented in table 2 .

TABLE 2. Observation of the Student Activities on Group Investigation Learning Model

\begin{tabular}{ccccccccc}
\hline \multicolumn{10}{c}{ Meeting to- } \\
\hline \multirow{2}{*}{ Student Activity (\%) } & $\mathbf{1}$ & $\mathbf{2}$ & $\mathbf{3}$ & $\mathbf{4}$ & $\mathbf{5}$ & $\mathbf{6}$ & $\mathbf{7}$ & Mean \\
\cline { 2 - 10 } & 6.67 & 75.00 & 85.42 & 91.67 & 95.83 & 95.83 & 97.92 & 86.90
\end{tabular}




\section{Analysis of Student Performance on Critical Thinking Ability Test Math}

This analysis is intended to know locate students' weaknesses in the critical thinking ability of mathematics.

TABLE 3. The Mean Every Aspect of Critical Thinking Ability Math Students Judging from the Use of Learning Model

\begin{tabular}{ccccccc}
\hline & \multicolumn{3}{c}{ Learning Model } \\
\hline \multirow{2}{*}{$\begin{array}{c}\text { Indicator Critical } \\
\text { Thinking Math }\end{array}$} & \multicolumn{3}{c}{ Group Investigation } & & Konventional \\
\cline { 2 - 7 } & $X$ Pretest & $X$ Posttest & N-Gain & $X$ Pretest & X Posttest & N-Gain \\
\hline Trigger Event & 10.38 & 17.38 & 0.73 & 9.94 & 14.38 & 0.44 \\
Exploration & 0.09 & 15.18 & 0.76 & 0.06 & 8.94 & 0.45 \\
Analyzing & 4.35 & 12.76 & 0.55 & 4.75 & 8.28 & 0.24 \\
Clarification & 3.29 & 10.15 & 0.41 & 2.88 & 6.34 & 0.21 \\
Resolution & 1.12 & 7.68 & 0.35 & 1.19 & 3.69 & 0.14 \\
\hline
\end{tabular}

Description: The ideal score of each aspect was 20.

\section{Differences of Critical Thinking Ability Mathematical Students Taught with Group Investigation Learning Model and Students Taught with Conventional Learning Model}

Before performing the difference test of critical thinking ability mathematical between the two classes, first tested the normality of the data from both study groups as shown in Table 4.

TABLE 4. Normality Test Data N-Gain Critical Thinking Ability Math Students Second Group of

\begin{tabular}{llllllc}
\multicolumn{1}{c}{ Learning Model } & n & Mean & Kolmogorov Smirnov Z & Sig. & $\mathbf{H}_{\mathbf{0}}$ \\
\hline Group Investigation & 34 & 0.55 & 0.66 & 0.77 & Accepted \\
Konventional & 32 & 0.29 & 0.55 & 0.92 & Accepted
\end{tabular}

Table 4 shows that both the Sig. greater than $\alpha=0.05$, which means that Ho was accepted. Thus, it can be concluded that the study group had a second data sample comes from a population that is normally distributed. Furthermore, the homogeneity of variance between the two studies groups as shown in Table 5.

TABLE 5. Homogeneity Test of Variance Data N-Gain Critical Thinking Capability Math Students between Both Group Learning

\begin{tabular}{ccc}
\multicolumn{3}{c}{ Capability Math Students between Both Group Learning } \\
\cline { 2 - 3 } & \multicolumn{2}{c}{ Levene's Test for Equality of Variances } \\
\cline { 2 - 3 } N-Gain & F & Sig. \\
\hline
\end{tabular}

Table 5 shows that the value of Sig. amounted of 0.476 greater than $\alpha=0.05$, which means that $\mathrm{H}_{0}$ is accepted. Thus, it can be concluded that the second data learning groups have homogeneous variances. Statistical tests were used to test the hypothesis was t-test with the testing criteria: reject $\mathrm{H}_{0}$ if the value $1 / 2$ sig. $<\alpha$ and accept $\mathrm{H}_{0}$ if the value of $1 / 2$ sig. $>\alpha$ at the level of $95 \%$ or error level $\alpha=0.05$. The results of data analysis to test the hypothesis presented in Table 6.

Statistical tests were used to test the hypothesis was t-test with the testing criteria: reject $\mathrm{H}_{0}$ if the value $1 / 2$ sig. $<\alpha$ and accept $\mathrm{H}_{0}$ if the value of $1 / 2 \mathrm{sig}$. $>\alpha$ at the level of $95 \%$ or error level $\alpha=0.05$. The results of data analysis to test the hypothesis presented in Table 6.

TABLE 6. Significance Test of Difference Critical Thinking Ability of Mathematics between Second Class Learning

\begin{tabular}{|l|l|l|l|l|l|l|l|}
\hline Learning Model & $\mathbf{n}$ & Mean & Standard Deviation & t & df & Sig. & Ho \\
\hline Group Investigation & 34 & .55 & 0.12 & \multirow{3}{*}{8.34} & \multirow{2}{*}{64} & \multirow{2}{*}{0.00} & Rejected \\
\cline { 1 - 4 } & 32 & 0.29 & 0.13 & & & & \\
\hline
\end{tabular}


The test results in Table 6 shows that the t-value of 8.34 and a significance value of 0.00 is smaller than $\alpha=0.05$, which means that $\mathrm{H} 0$ is rejected. It can be concluded that there are differences in critical thinking ability mathematics between students taught by group investigation learning model and the students taught by conventional learning models. From mean value of the $\mathrm{N}$-Gain derived from both study groups can be concluded that the application of learning models investigation group more influential than the application of conventional learning model to mathematics students' critical thinking ability.

\section{DISCUSSION OF RESEARCH}

Based on the research that has been described previously, it is known that the application of group investigation learning models more influential than the application conventional learning model to mathematics students' critical thinking ability. The group of students who got the group investigation learning model has the ability to think critically higher mathematics than students who received conventional learning models.

\section{Learning Model of Group Investigation}

Group Investigation learning model used by teachers significantly influence the improvement of mathematics students' critical thinking skills as well as activities of students during the learning process. In the group of students who received conventional learning model, the teachers is central to the activities of the learning process and make students play a passive role. As a result, students become less interested in the material being taught, do not cultivate the curiosity of students to the material being studied, the students quickly get bored and expect the learning process ends soon so less able to understand and develop critical thinking skills. It can be seen from the results of research that has been explained previously that the critical thinking skills of mathematics students who received conventional learning models lower than students who received teaching model group investigation. In the process of learning by using learning model group investigation, the student is central to the learning process, facilitating students to conduct an inquiry/investigation so that students interested in the learning process and take an active role in constructing the critical thinking skills. Therefore, by using group investigation learning model can develop critical thinking ability of mathematics students.

Group Investigation learning model is designed to help students develop thinking skills and problem-solving skills in this regard is the ability to think critically mathematics. Group investigation begins with teachers lead students on the topic/problem in learning trigonometry, motivate students by providing an implementation issue in the context of a real trigonometric ratio. It can arouse the curiosity of students so that they are keen to investigate topics related to trigonometry.

After students receive the topics presented by the teacher, then the students form study groups and to investigate and solve the problems given in LKS. Topics covered in worksheets tailored to the situation authentic and meaningful issues that can provide convenience to students for conduct an investigation and inquiry. Investigations conducted in groups can help develop the investigations carried out and facilitate students in collecting data or information needed in the investigation process. After collecting the data, each group of students to discuss the solution of the existing problems. Based on the above it can be concluded that there is a correlation between the learning model group investigations with critical thinking ability of mathematics students. The Application of group investigation learning model more significant effect than the application of conventional learning model to critical thinking ability of mathematics students'.

\section{Critical Thinking Ability of Mathematics Students'}

Critical thinking skills of mathematics are the student's ability to solve problems systematically. Students who have the critical thinking ability demonstrated by its ability in solving mathematical problems using aspects of the trigger event, exploration, analyzing, clarification and resolution. Increased capacity is greatly influenced by the used of the learning model.

Table 1 and Table 3 shows that after students are taught by group investigation learning model and conventional learning models, critical thinking ability of mathematical students has increased in every aspect of critical thinking ability. Students who receive learning model group investigation gain greater improvement from every aspect of critical thinking ability of mathematics than students who received conventional learning models. Based on the increase in every aspect of critical thinking ability of mathematics on students that are taught with group 
investigation learning model, the exploration aspect of the student's ability to define the concepts used in problem solving is an aspect with the highest increase in the amount of 0.75 (high category) and aspects of the resolution: the ability students to retest / decisive conclusion is an aspect with the lowest increase in the amount of 0.35 (medium category).

Based on the students' work to resolve any question critical thinking ability mathematics which given after taught by group investigation learning model, it appears that students are able to identify and understand a given problem and define the concept of what can be used to solve the problem. However, in applying the concepts and solve problems most students erred in the calculation process that led to the next aspect was not optimal, and not a few students who are wrong in choosing the proper concept of the problem set by causing the calculation and the final result was not optimal.

In the experimental class, the exploration aspect (determining the concept of the right) received the highest increase compared to other aspects of critical thinking ability. This is caused by the learning model group investigation emphasis on the process of the investigation of a topic, wherein when the students were in the middle of the course of their research to address the problem, the students build the knowledge they gained, instead of receiving the teacher to them [2]. Thus, the concept of which they found to be embedded with the good.

The results of the above study both descriptively and inferentially have shown significant differences of critical thinking ability mathematics students are taught group investigation learning model and the students taught by conventional learning models. It can be concluded that the application of group investigation learning models more influential than the application conventional learning model to critical thinking ability of mathematics students'.

\section{CONCLUSIONS}

Based on the research result and discussion, it can be concluded that:

28. There are influence the application of group investigation learning model of the critical thinking ability of mathematics students with mean N-Gain of 0.55 (medium)

29. There are influence the application of conventional learning models to the critical thinking ability of mathematics students with mean N-Gain of 0.283 (low)

30. Application of group investigation learning model more influential than the application conventional learning model to critical thinking ability mathematics students'

\section{ACKNOWLEDGMENTS}

I acknowledged Allah SWT, Rasulullah SAW, my family, Department of Mathematics Education, Halu Oleo University, and others who have helped in the preparation of this paper.

\section{REFERENCES}

1. Fahinu, "Improve Critical Thinking Ability and Independence Learning Mathematics in Student Learning Through Generative", Dissertation, UPI. 2007.

2. S. Sharan, The Handbook of Cooperative Learning (Istana Media, Yogyakarta: Istana Media, 2014), pp. 131.

3. Trianto, Model-Oriented Innovative Learning Model Constructivist: Theoretical-Practical Platform Concept and Implementation, (Prestasi Pustaka Publisher, Jakarta, 2007), pp. 25.

4. R. Agustina, "Efforts to Improve Students Interest in Learning through Group Investigation Learning Model on Course for Environmental Science in Biology Education Studies Program FKIP Unigha", Science Research, Vol. 1-No. 2 